\title{
STUDY OF SEA LEVEL RISE USING SATELLITE ALTIMETRY DATA IN THE SEA OF DUMAI, RIAU, INDONESIA
}

\author{
D. Ariana ${ }^{a}$, C. Kusmana ${ }^{b}$, Y. Setiawan ${ }^{c, d}$ \\ a Graduate Program of Natural Resources and Environmental Management, Bogor Agricultural University, Indonesia \\ ${ }^{b}$ Department of Silviculture, Faculty of Forestry, Bogor Agricultural University, Indonesia \\ c Department of Forest Conservation and Ecotourism, Faculty of Forestry, Bogor Agricultural University, Indonesia \\ ${ }^{d}$ Environmental Research Center, Bogor Agricultural University, Indonesia
}

\section{Article Info:}

Received: 29 November 2016

in revised form: 13 January 2017

Accepted: 26 February 2017

Available Online: 27 March 2017

\section{Keywords:}

Sea level rise, satellite altimetry, sea level anomaly

\section{Corresponding Author:}

Dewi Ariana

Graduate Program of Natural Resources and Environmental Management, Bogor Agricultural University, Indonesia Email: dewiariana1515@yahoo.com

\begin{abstract}
Climate change and global warming has impacted the entire world. It has caused ice melting at the poles, climate extreme event, land subsidence which further affected sea level to rise, such as particularly, in Dumai coastal areas. To date, sea level rise is one of the important global issues. This increases the vulnerability effect in coastal areas which threatens human life, especially those living in coastal regions. Sea level rise can be forecasted by satellite imagery like ENVISAT, Topex/Poseidon, Jason-1 and Jason-2. This paper presents an approach to quantify the sea-level variations and sea level trend based on a combination of multi-mission satellite altimetry data over a period of 21 years (1993-2014). Monitoring of sea level rise was conducted by taking data from 6 stations. SLA was calculated using a typical moving average to reduce fluctuation. Sea level rise was calculated using a linear regression. Positive sea-level linear trends for the analysis period were estimated for sea level rise. The results showed that the range sea level rise reaching $4.80 \mathrm{~mm} /$ year to $5.61 \mathrm{~mm} /$ year has occured in Dumai. Dumai is predicted to have an additional sea level of 0.17-0.20 $\mathrm{m}$ by the year 2050, 0.41-0.48 $\mathrm{m}$ by the year 2100 and $0.65-0.76 \mathrm{~m}$ by the year 2150 . The sea level rise trends in the North West part Dumai were higher than the other stations and down to South East. Based on the predicted results, Dumai should prepare plans to mitigate the rising of sea levels.
\end{abstract}

How to cite (APA 6th Style):

Ariana, D., Permana, C., \& Setiawan, Y. (2017). Study of sea level rise using satellite altimetry data in the sea of Dumai, Riau, Indonesia. Geoplanning: Journal of Geomatics and Planning, 4(1), 75-82. doi: 10.14710/geoplanning.4.1.75-82

\section{INTRODUCTION}

Melting of polar ice as a result of rising global temperatures has caused sea level to rise. The trend of rising sea levels was directly proportional with the trend of rising global temperatures. Measurements of the increase in sea level have been made since the 18th century by utilizing the tide data. Having a vast marine area, Indonesia has a lot of latent potential in the oceans. On the other hand, the oceans could pose a threat to the surrounding lands; such as the phenomenon of sea level rise.

The Intergovernmental Panel on Climate Change (IPCC) in 2001 has reported such activity during the 20th century. The sea level rise that occurred was in the estimation of $2.2 \mathrm{~mm} /$ year (Ilk, Flury, \& Rummel, 2005). This indicates that the effect of melting ice on the rise in global sea level has changed (Llovel, Guinehut, \& Cazenave, 2010). In the previous decade (1993-2003), 50\% of sea level rise was affected by thermal expansion of the oceans and $40 \%$ by melted land ice (Bindoff et al., 2007). The occurrence of extreme high water events related to storm surges, high tides, surface waves, and flooding rivers will equally increase. Flooding and loss of land will have significant impacts on humans, wildlife, and entire ecosystems (Radzi \& Ismail, 2013). 
Measurement of variations in sea level with complete basin coverage would provide constraints on the water mass balance and thermal expansion of seawaters in response to climate change. Satellite altimetry, operational for nearly one decade could provide important information of mean sea level changes on time scales ranging from one month to several years with high spatio-temporal coverage (Cazenave, 2002). Long-term sea level change is important for a variety of environmental and socio-economic reasons, especially for the large portion of the world's population living in the coastal zone (Fu \& Cazenave, 2000). Quite importantly, this technique provided access to the geographical variations of the sea level changes which might certainly not be uniform over the basin (Cazenave, 2002). Sea level rise due to climate change was globally non uniform, necessitating regional estimates (Luu, Tkalich, \& Tay, 2015). While tide gauge sea level measurements could show apparent sea level trends due to bias and drift in the instrument as well to a change in the reference point and land motion (Cazenave, 2002). Correspondingly, satellite altimetry could show spurious sea level change due to instability (Mitchum et al., 2001) in the instrument and not homogeneity of the geophysical corrections (Scharroo \& Smith, 2010).

Generally, radar altimetry is among the simplest of remote sensing techniques. Two basic geometric measurements are involved in this technique. Firstly, the distance between the satellite and the sea surface is determined from the round-trip travel time of microwave pulses emitted downward by the satellite"s radar, reflected back from the ocean, and received again on board. Secondly, independent tracking systems are used to compute the satellite's three-dimensional position relative to a fixed earth coordinate system. Then, combining these two measurements yields profiles of sea surface topography, or sea level, with respect to the reference ellipsoid (a smooth geometric surface which approximates the shape of the Earth) (Fu \& Cazenave, 2000).

In recent years, identifying and explaining signals contributing to regional and global sea level variability and trends has been frequently studied problems (Ablain et al., 2015; Bromirski et al., 2011; Chambers, Merrifield, \& Nerem, 2012; Fasullo et al., 2013; Frankcombe, McGregor, \& England, 2015; Hamlington et al., 2014; Hamlington et al., 2011; Hamlington et al., 2013; Moon et al., 2013; Zhang \& Church, 2012). In this research, we focused on an area of the Dumai region and its surroundings. Dumai sea waters were selected as the study area because Dumai's location is bounded by Malacca Strait. The sea level along the peninsula might be influenced by Malacca Strait. Luu et al. (2015) reported that SLAs in the Malacca Strait side was further correlated in the range of $\pm 5 \mathrm{~cm}$ with the Indian Ocean Dipole (IOD). Interannual regional sea level falls are associated with El Nino events and positive phases of IOD, whilst rises are correlated with lanina episodes and negative values of the IOD index. Dumai as coastal area is prone to damage caused by rob $b^{1}$ flood. In addition, altimeter studies was limited in this region. This study presented the sea level variations and sea level trend of Dumai Sea based on a combination of multi-mission satellite altimeters over a period of 21 years, from 1993 to 2014. The data were extracted from six altimeter missions, i.e., TOPEX, Jason-1, Jason-2, ERS-1, ERS- 2, and Envisat. We also carried out sea level prediction for Dumai Sea Waters.

\section{DATA AND METHODS}

\subsection{Data Set in This Study}

Merged maps of sea level anomalies (MSLA) were used, as extracted from TOPEX, Jason-1, Jason-2, ERS-1, ERS-2, and Envisat (provided by the Archiving, Validation, and Interpretation of Satellite Oceanographic (AVISO) data (http://www.aviso. oceanobs.com/). In addition, multi-mission gridded satellite altimetry data were used (Cazenave, 2002; Fenoglio-Marc, 2002; Pascual et al., 2009). Gridded data of $0.25^{\circ} \times 0.25^{\circ}$ sea level anomalies maps were adopted from January 1993 to December 2014. The altimetric measurements were corrected for atmospheric effects (ionospheric delay and dry/ wet tropospheric effects) and geophysical processes (solid, ocean, and pole tides, loading effect of the ocean tides, sea state bias, and the Inverted Barometer response of the ocean). Detailed information of the corrections can be found at the AVISO website. Point of observation in sea of Dumai can be viewed in Table 1 and Figure 1.

\footnotetext{
${ }^{1}$ Rob is the Indonesian Local term for sea level rise
} 
Table 1. The station coordinate in study area

\begin{tabular}{|c|c|c|}
\hline Station & Longitude & Latitude \\
\hline 1 & 101.125 으 & $2.375 \mathrm{oN}$ \\
\hline 2 & 101.375 oE & $2.125 \mathrm{oN}$ \\
\hline 3 & 101.375 oE & $1.875 \mathrm{oN}$ \\
\hline 4 & 101.875 oE & $1.625 \mathrm{oN}$ \\
\hline 5 & 101.375 oE & 2.375 oN \\
\hline 6 & 101.875 oE & $1.875 \mathrm{oN}$ \\
\hline
\end{tabular}

Figure 1. The Map of Dumai (Geospatial Information Agency, 2014)

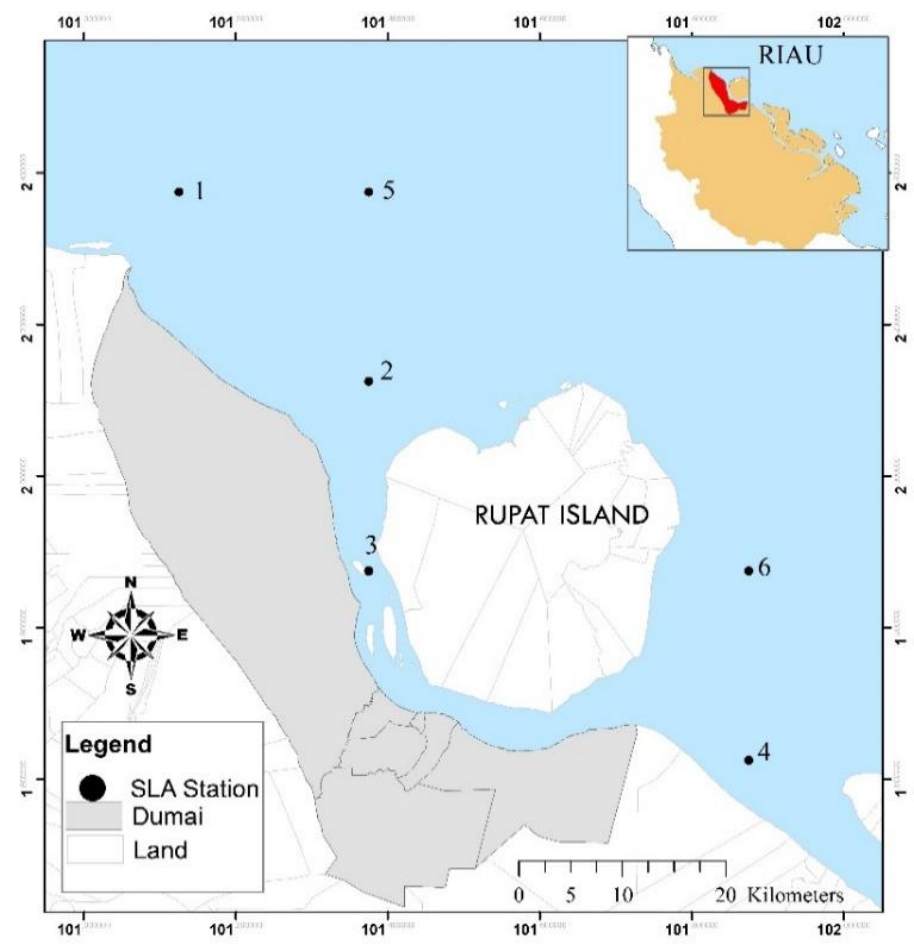

\subsection{Data Analysis}

Stages of data processing were as follow. Multi-mission gridded satellite altimetry data were downloaded from http://www.aviso.oceanobs.com. The data was selected in the period January 1993 to December 2014. Selection period and data domain was conducted into a desired location domain. Sea level rise trend data processing started with extracting the data in netCDF format (*.nc) using ODV-4 (Ocean Data View 4) into in text format (*.txt) in the interest area. In this study, six stations were taken. Sea level anomalies data obtained was manually converted into months. To reduce fluctuation, SLA was calculated using a typical moving average (Gencay, 1996). It can be written as

$$
m_{t}^{n}=(1 / n) \sum_{i=0}^{n-1} p_{t-i}
$$

Let $m_{t}^{n}$ denote the time $t$ value of a moving average rule of length $n$. Let $p_{t}, t=1,2, \ldots, \mathrm{T}$, be monthly SLA series. An $n$-period moving average is computed by adding together the $n$ most recent periods of data, then dividing by $n$. This average is recalculated each period by dropping the oldest data and adding the most recent, so the average moves with the data but does not fluctuate as much. An $n$-period moving average is smoother than an $i$-period (where $i<n$ ) moving average and measure a longer-term trend. 
The SLA value for each month was plotted into a graph to show the changes in sea level over time. The result was a linear trend rise in sea level at the observation stations. Sea level rise was calculated using a linear regression equation as follow:

$$
Y=a x+b
$$

Where: $y$ is the dependent variable (the trend of sea level rise); $x$ is independent variable (time), in this case is the total months. Based on the linear regression equation, sea level rise per year can be determined. The increasing trend per year was calculated using a modified formula in Cahyadi, Jaelani, \& Dewantoro (2016) as follow:

Trend per year $=\frac{Y_{n}-Y_{0}}{t}$

Where: $Y$ is the value of sea level rise in month $n, Y_{0}$ is sea level rise in initial calculation, $n$ total of months, and $t$ total of years.

From the linear regression, the sea level rise per year was calculated. Based on the trend line plotted, the fitted linear regression model was determined. The equation demonstrates whether the trend has increased or decreased over time, and if it has, how quickly or slowly the increase or decrease has occurred. Furthermore, the gridding value of sea level rise was obtained using software Surver 13 to show changes in the form of $2 \mathrm{D}$ color contour map and get the image visualization. In this study, gridding was obtained using DIVA gridding interpolation. From interpolation calculations obtained results from gridding value of sea level rise in the form of sea level data in the sea territory of Dumai per year within 21 years. Sea level data was then plotted to obtain sea level trend image. With the assumption sea level rise is static year to year, an estimation of the sea level rise (SLR) rate in the year 2050, 2100, and 2150 was obtained by making future projection using the equation.

\section{RESULTS AND DISCUSSION}

Before analyzing the trend variability in Dumai region, sea level anomaly (SLA) was compared. Based on monthly SLA data and chart changes in sea level fluctuations, the maximum and minimum SLA for 21 years was obtained. The SLA values are shown in Table 2. The maximum SLA occurred mostly in October 2010 and the minimum occurred in November 1997. The influence from the seasonal anomaly of sea level in the Malacca Strait was suspected. The phenomenon of the seasonal anomaly of sea level in the Malacca Strait has been explained by Luu et al. (2015). The complexity of the pattern is arguably due to competition between seasonal wind from the South China Sea, and wind stress locally established over the Andaman Sea and directed toward the Malacca Strait.

Table 2. SLA minimum and maximum (Analysis, 2016)

\begin{tabular}{ccccc} 
Station & & & SLA (m) & Period \\
\hline $\mathbf{1}$ & Min & Period & Max & November 1995 \\
\hline $\mathbf{2}$ & -0.24 & November 1997 & 0.21 & October 2010 \\
\hline $\mathbf{3}$ & -0.22 & November 1997 & 0.22 & October 2010 \\
$\mathbf{4}$ & -0.20 & November 1997 & 0.22 & October 2010 \\
$\mathbf{5}$ & -0.18 & November 1997 & 0.23 & October 2010 \\
$\mathbf{6}$ & -0.23 & November 1997 & 0.21 & October 2010 \\
\hline
\end{tabular}

Sea level trends in areas adjacent to Dumai Sea Waters have been analyzed. The entire six station showed a trend of sea level rise with different values. The SLA linear trends are shown in Figure 2. The coefficient of determination and correlation in all stations were ranged from 0.384-0.467 and from 0.620.68. SLA. Statistically, date (time) has significant correlation. Furthermore, changes in sea surface (both 
increases and decreases) were due to several factors. Llovel et al. (2010) has stated that the most influential factor to changes in sea level is the regional and global changes in steric sea level. Changes steric sea level is defined as the change in the density of the water column due to temperature and salinity anomalies.

Figure 2. (a) SLA trend in station 1, (b) SLA trend in station 2, (c) SLA trend in station 3, (d) SLA trend in station 4, (e) SLA trend in station 5, (f) SLA trend in station 6 (Analysis, 2016).

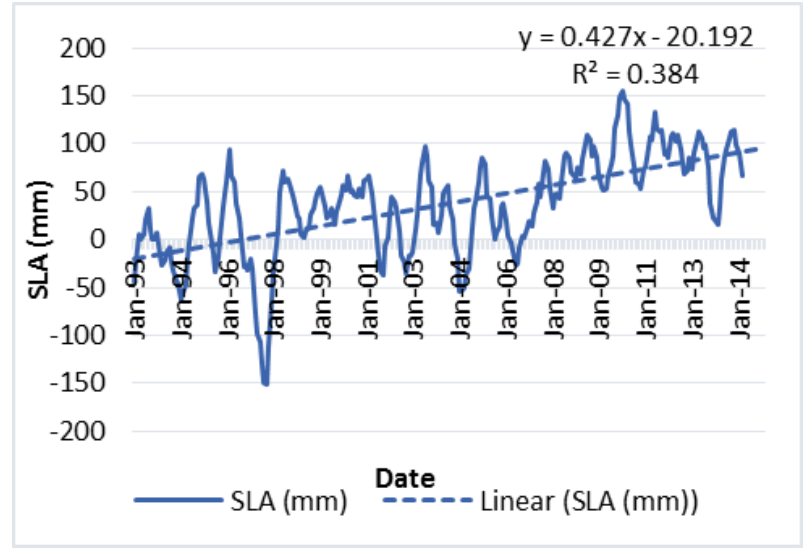

(a)

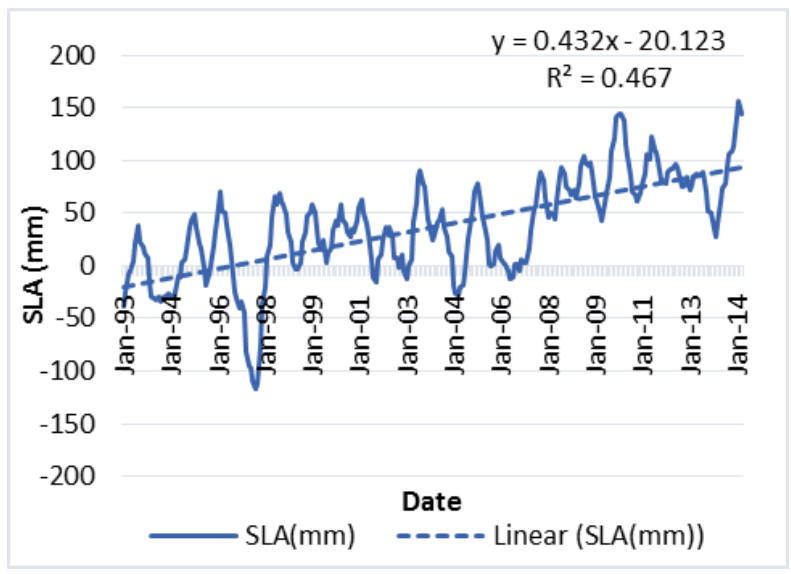

(c)

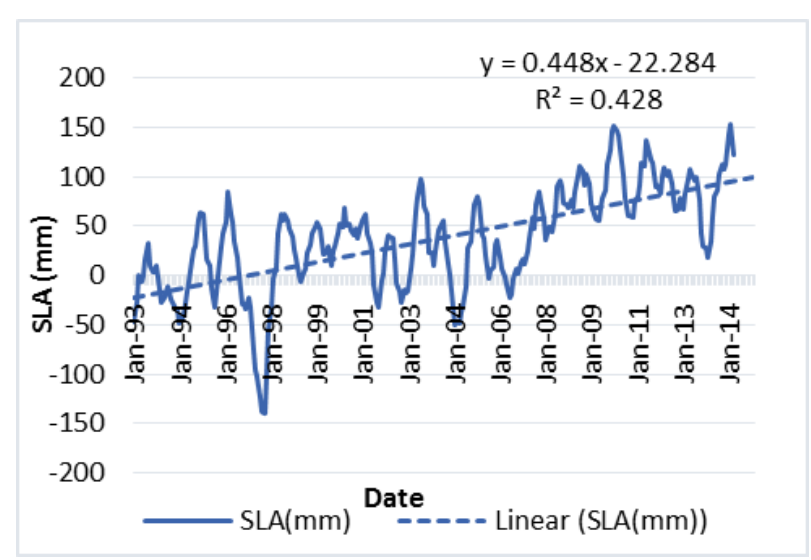

(e)

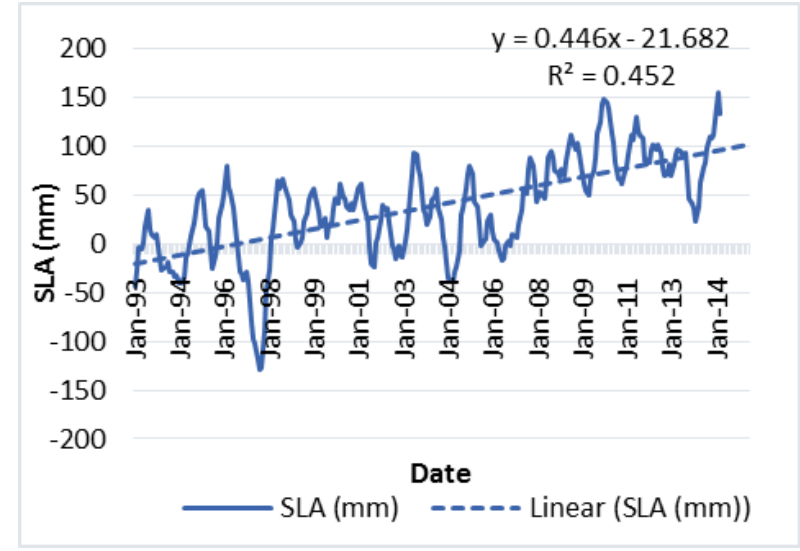

(b)

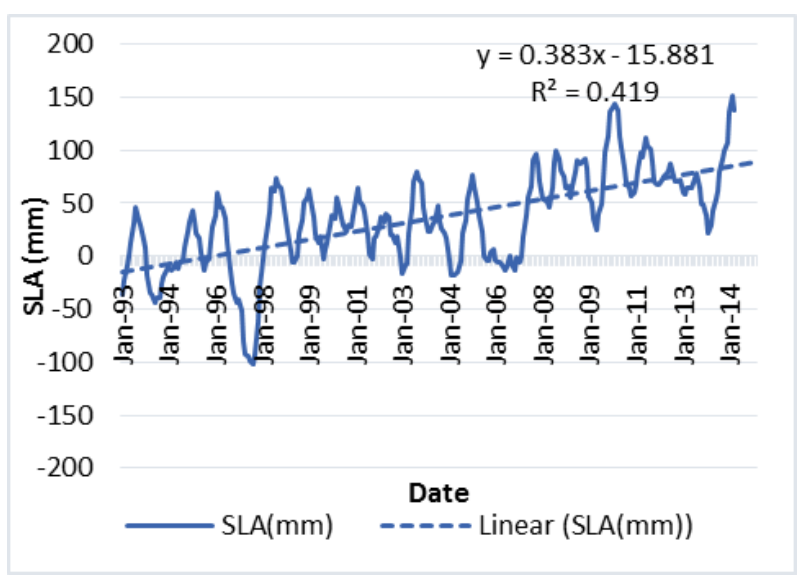

(d)

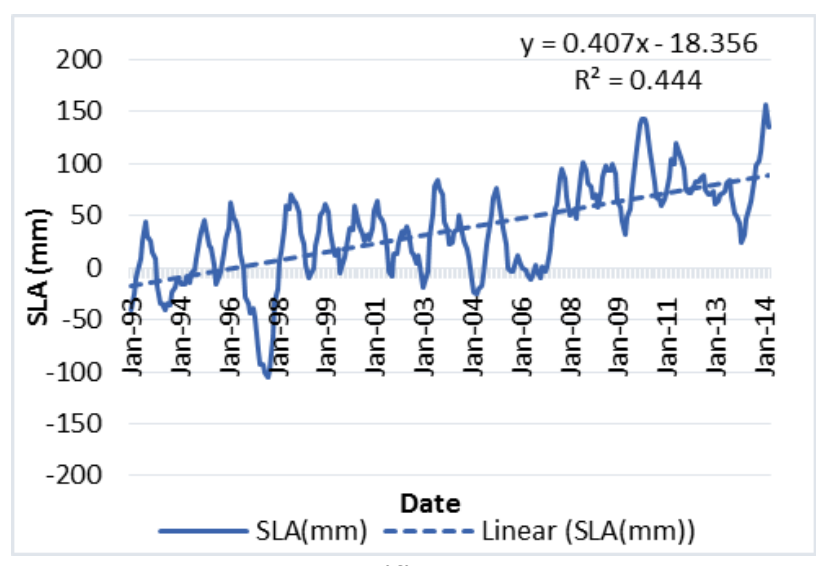

(f) 
The data trend of sea level rise of Dumai and its surrounding area showed a higher sea level in the North West part Dumai compared to the other stations and down to South East Dumai. The trend of this sea level rise is shown in Table 3 and Figure 3. The highest sea level rise of $5.61 \mathrm{~mm} /$ year was recorded in station 5 approaching the Strait of Malacca while the lowest was $4.72 \mathrm{~mm} /$ year in station 4 . Trends in sea level rise are consistent with research of Alfian (2015) which stated that the rise in sea level in the waterway facing Aceh was $10.575 \mathrm{~mm} /$ year. So the trend of sea level rise has increased from Dumai waters North West towards the ocean waters in the Malacca Strait.

Dumai sea level rise trend are shown in Table 3. Value of sea level rise was slightly different from research Luu et al. (2015) which stated that their corresponding geocentric sea level rise rates of Malacca Strait were estimated $4.4 \pm 3.1 \mathrm{~mm} /$ year from tide gauge record entire period, wheares sea level rise rate from satellite altimetry $4.1 \pm 1.9 \mathrm{~mm} /$ year (1993-2013). According to Din (2012), the altimeter sea level time series revealed that using multi-mission altimetry data since 1993 to 2008, the mean sea level in Malaysian seas has been rising at a geographically-dependent rate varying from 1.4 to $4.1 \mathrm{~mm} /$ year. This value was lower than sea level trend rate of Dumai sea water. Based on Williams (2013), during the 20th century, sea level began rising at a global average rate of $1.7 \mathrm{~mm} / \mathrm{year}$. The current average rise rate is 3.1 $\mathrm{mm} /$ year, a $50 \%$ increase over the past two decades. Taken together, the result showed that sea level rise value of Dumai was higher than the world's.

Table 3. Trend sea level rise in study area in the period 1993-2014 (Analysis, 2016)

\begin{tabular}{|ccc|} 
Station & Sea level rise trend along twenty one years $(\mathbf{m m})$ & Sea level rise trend $(\mathbf{m m} /$ year $)$ \\
\hline $\mathbf{1}$ & 112.25 & 5.35 \\
\hline $\mathbf{2}$ & 117.30 & 5.59 \\
\hline $\mathbf{3}$ & 113.62 & 5.41 \\
$\mathbf{4}$ & 100.73 & 4.80 \\
\hline $\mathbf{5}$ & 117.82 & 5.61 \\
\hline $\mathbf{6}$ & 107.04 & 5.10 \\
\hline
\end{tabular}

The range of sea level rise in Dumai reached 4.80-5.61 mm/year. The measured value at each station was higher than global sea level rise reaching $3.2 \pm 0.4$ in the period 1993-2013 and $3.3 \pm 0.4$ in the period 1993-2009. Trends in the region over this time period are strictly positive and approach values greater than $1 \mathrm{~cm} /$ year in some areas. Trend values in the southeastern part of the Southeast Asian sea region have been particularly high in the past two decades. According to Nicholls and Cazenave (2010), two main factors contributing to SLR were (i) thermal expansion of sea water due to ocean warming and (ii) water mass input from land ice melt and land water reservoirs. It is also then assumed that the factors contributing of Dumai sea level rise are potentially thermal expansion of sea water and land ice melt input.

Figure 3. Dumai trend sea level rise (Analysis, 2016)

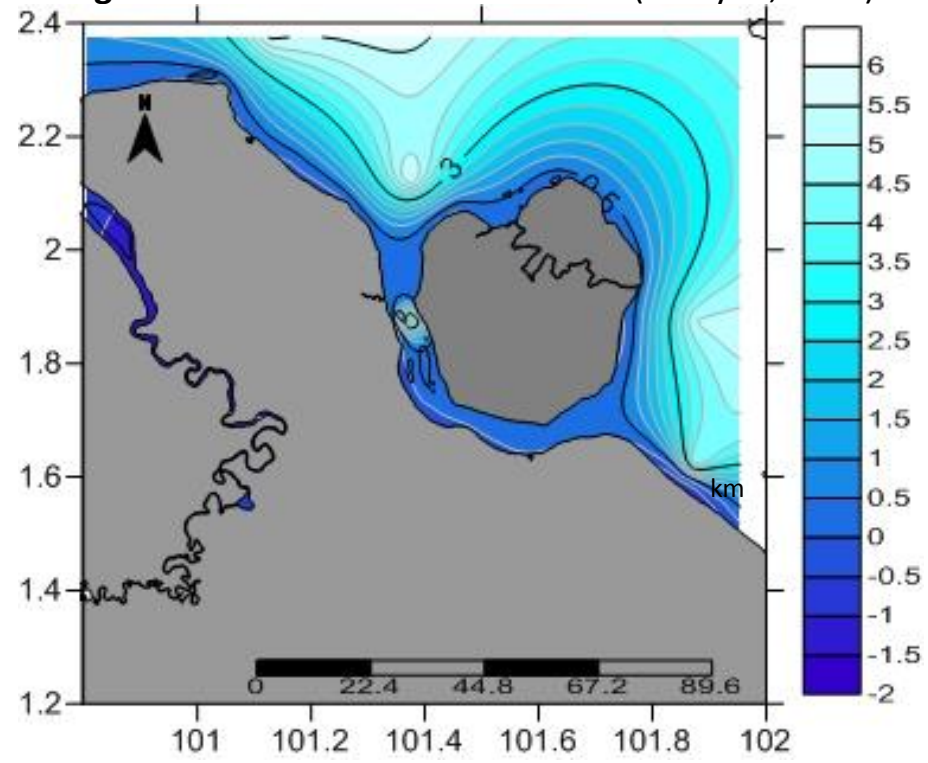


Sea level rise occurs in Dumai Sea Waters every year. The SLA values were shown in Table 3. Using this research, prediction of sea level was carried out. Dumai sea level rise prediction is shown in Figure 3. Based on the obtained prediction, rate of sea level rise in Dumai sea waters was $0.41-0.48 \mathrm{~m}$ per 100 years or 0.004-0.0048 $\mathrm{m}$ per year. Using the assumption that the rise in sea level is constant every year, the sea level rise for the Dumai will be $0.17-0.20 \mathrm{~m}$ by the year $2050,0.41-0.48 \mathrm{~m}$ by the year 2100 and $0.65-0.76 \mathrm{~m}$ by the year 2150 (Table 4).

Table 4. Dumai sea level rise prediction per 50 years (Analysis, 2016)

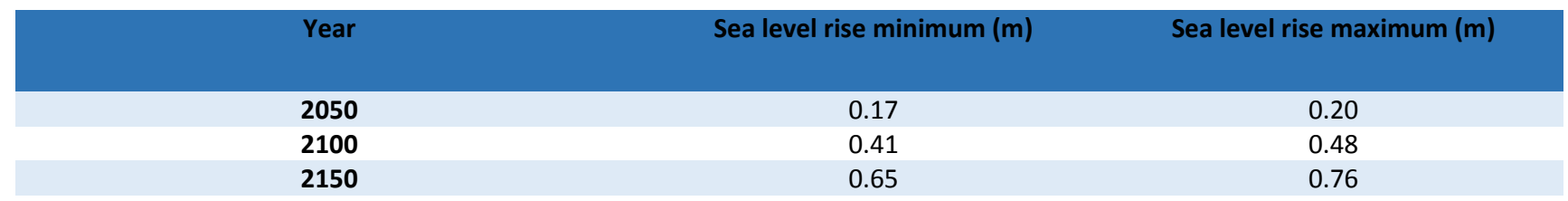

\section{CONCLUSION}

Trends of sea level rise of the Dumai Sea water were evaluated using satellite altimetry data along 21 years (from 1993 to 2014). From the analysis, the results showed that Dumai Riau have an upward trend of sea level rise. The rate of SLR lied between $4.80 \mathrm{~mm} /$ year to $5.61 \mathrm{~mm} /$ year. Dumai, Riau was predicted to have an additional sea level which of be $0.17-0.20 \mathrm{~m}$ by the year 2050, 0.41-0.48 $\mathrm{m}$ by the year 2100 and 0.65-0.76 $\mathrm{m}$ by the year 2150. The data trend of sea level rise of Dumai and its surrounding area showed a higher sea level in the North West part Dumai compared to the other stations and down to South East Dumai. Based on the predicted results, Dumai should prepare plans to mitigate the rising of sea levels.

\section{ACKNOWLEDGMENTS}

The altimeter products were produced by SSALTO/DUACS and distributed by AVISO with support from CNES. The authors thank equally the BOPTN DIKTI for support in this research.

\section{REFERENCES}

Ablain, M., et al. (2015). Improved sea level record over the satellite altimetry era (1993-2010) from the Climate Change Initiative project. Ocean Science, 11(1), 67-82. [CrossRef]

Alfian, N. R. H. (2015). Analysis of Sea Level Rise Phenomenon in Indonesian Waters Based on Satellite Altimetry Jason-2 Data for Period 2009-2012. Institut Teknologi Sepuluh November.

Din, A. H. M. (2012). Long-term sea level change in the Malaysian seas from multi-mission altimetry data. International Journal of Physical Sciences, 7(10). [CrossRef]

Bindoff, N. L., et al. (2007). Observations: oceanic climate change and sea level.

Bromirski, P. D., et al. (2011). Dynamical suppression of sea level rise along the Pacific coast of North America: Indications for imminent acceleration. Journal of Geophysical Research, 116(C7), C07005. [CrossRef]

Cahyadi, M. N., Jaelani, L. M., \& Dewantoro, A. H. (2016). Study of sea level rise using satellite altimetry data (A case study: Sea Of Semarang). Geoid, 11(2), 176-183.

Cazenave, A. (2002). Sea level variations in the Mediterranean Sea and Black Sea from satellite altimetry and tide gauges. Global and Planetary Change, 34(1-2), 59-86. [CrossRef]

Chambers, D. P., Merrifield, M. A., \& Nerem, R. S. (2012). Is there a 60 -year oscillation in global mean sea level? Geophysical Research Letters, 39(18). [CrossRef]

Fasullo, J. T., et al. (2013). Australia's unique influence on global sea level in 2010-2011. Geophysical Research Letters, 40(16), 4368-4373. [CrossRef]

Fenoglio-Marc, L. (2002). Long-term sea level change in the Mediterranean Sea from multi-satellite altimetry and tide gauges. Physics and Chemistry of the Earth, Parts A/B/C, 27(32-34), 1419-1431. [CrossRef]

Frankcombe, L. M., McGregor, S., \& England, M. H. (2015). Robustness of the modes of Indo-Pacific sea level variability. Climate Dynamics, 45(5-6), 1281-1298. [CrossRef] 
Fu, L.-L., \& Cazenave, A. (2000). Satellite altimetry and earth sciences: a handbook of techniques and applications (Vol. 69). Academic Press.

Gencay, R. (1996). Non-linear prediction of security returns with moving average rules. Journal of Forecasting, 15(3), 165-174.

Hamlington, B. D., et al. (2011). The Effect of Signal-to-Noise Ratio on the Study of Sea Level Trends. Journal of Climate, 24(5), 1396-1408. [CrossRef]

Hamlington, B. D., et al. (2013). Contribution of the Pacific Decadal Oscillation to global mean sea level trends. Geophysical Research Letters, 40(19), 5171-5175. [CrossRef]

Hamlington, B. D., et al. (2014). Uncovering an anthropogenic sea-level rise signal in the Pacific Ocean. Nature Climate Change, 4(9), 782-785. [CrossRef]

Ilk, K. H., Flury, J., \& Rummel, R. (2005). Mass Transport and Distribution in the Earth System. Technise Universitat Munchen.

Llovel, W., Guinehut, S., \& Cazenave, A. (2010). Regional and interannual variability in sea level over 20022009 based on satellite altimetry, Argo float data and GRACE ocean mass. Ocean Dynamics, 60(5), 1193-1204. [CrossRef]

Luu, Q. H., Tkalich, P., \& Tay, T. W. (2015). Sea level trend and variability around Peninsular Malaysia. Ocean Science, 11(4), 617-628. [CrossRef]

Mitchum, G. T., et al. (2001). The future of sea surface height observations. Observing the Oceans in the 21st Century. Melbourne, Australia: Bureau of Meteorology, 120-136.

Moon, J.-H., et al. (2013). Multidecadal regional sea level shifts in the Pacific over 1958-2008. Journal of Geophysical Research: Oceans, 118(12), 7024-7035. [CrossRef]

Nicholls, R. J., \& Cazenave, A. (2010). Sea-Level Rise and Its Impact on Coastal Zones. Science, 328(5985), 1517-1520. [CrossRef]

Pascual, A., et al. (2009). On the Quality of Real-Time Altimeter Gridded Fields: Comparison with In Situ Data. Journal of Atmospheric and Oceanic Technology, 26(3), 556-569. [CrossRef]

Radzi, A. B. A., \& Ismail, H. B. (2013). Trend Analysis of Sea Level Rise for Kukup (Johor), West Coast of Peninsular Malaysia. In International Conference on Emerging Trends in Engineering and Technology (ICETET'2013).

Scharroo, R., \& Smith, W. H. F. (2010). A global positioning system-based climatology for the total electron content in the ionosphere. Journal of Geophysical Research: Space Physics, 115(A10). [CrossRef]

Williams, S. J. (2013). Sea-Level Rise Implications for Coastal Regions. Journal of Coastal Research, 63, 184196. [CrossRef]

Zhang, X., \& Church, J. A. (2012). Sea level trends, interannual and decadal variability in the Pacific Ocean. Geophysical Research Letters, 39(21), n/a-n/a. [CrossRef] 